\title{
A new species of Eucharissa Westwood (Eucharitidae) from South Africa, with an evaluation of the importance of pupae for assessing relationships in these ant parasitoids
}

\author{
John M. Heraty', Nokuthula Mbanyana², Simon Van Noorte,3 \\ I Department of Entomology, University of California, Riverside, CA 92521, Riverside, USA 2 Research \\ and Exhibitions Department, Iziko South African Museum, P.O. Box 61, Cape Town, 8000, South Africa \\ 3 Department of Biological Sciences, University of Cape Town, Private Bag, Rondebosch, 7701, South Africa \\ Corresponding author: John M. Heraty (john.heraty@ucr.edu)
}

\begin{tabular}{l}
$\frac{\text { Academic editor: Mark Shaw | Received } 30 \text { June } 2020 \mid \text { Accepted } 25 \text { August } 2020 \mid \text { Published } 30 \text { October } 2020}{\text { http://zoobank.org/EA7C5F1C-0D65-4EBO-BE84-991C955A1668 }}$ \\
\hline Citation: Heraty JM, Mbanyana N, Noort SV (2020) A new species of Eucharissa Westwood (Eucharitidae) from South \\
Africa, with an evaluation of the importance of pupae for assessing relationships in these ant parasitoids. Journal of \\
Hymenoptera Research 79: 43-55. https://doi.org/10.3897/jhr.79.56042
\end{tabular}

\begin{abstract}
Eucharissa (Hymenoptera: Eucharitidae) is an enigmatic genus within Chalcidoidea. Adults have at least 16 antennal segments, which is shared only by the closely related genus, Saccharissa, with some species of Eucharissa having as many as 22 antennal segments. At most, other Chalcidoidea have up to 14 segments. Phylogenetic analyses place Eucharissa within the poneromorph-ant attacking clade, but until now, the host and immature stages of this genus were unknown. Eucharissa insolita sp. nov. was discovered in two cocoons of Bothroponera granosa (Ponerinae) from South Africa; one a fully developed male and the other a second-instar larva. The larval exuviae present within the cocoons allowed for description of the life stages and comparison with other members of the poneromorph-attacking clade of Eucharitidae. Morphology of the pupa across Eucharitidae is reviewed, and synapomorphies of the immature stages are identified that support monophyly of the poneromorph-attacking clade within the tribe Eucharitini.
\end{abstract}

\section{Keywords}

ants, Formicidae, immatures, morphology, parasitism, pupa

Copyright John M. Heraty et al. This is an open access article distributed under the terms of the Creative Commons Attribution License (CC BY 4.0), which permits unrestricted use, distribution, and reproduction in any medium, provided the original author and source are credited. 


\section{Introduction}

Members of the family Eucharitidae are all parasitoids of the immature stages of ants. Their first-instar larvae, planidia, are carried into the ant nest by workers and transfer to the ant larvae where they initially attack and parasitize the host larva, but do not develop until the host pupates (Clausen 1940; Heraty 1994; 2000; 2002). When they emerge as adults, they use various means to deceive the ants, ranging from acquisition of host cuticular hydrocarbons (Vander Meer et al. 1989) to chemical mimicry (Pérez-Lachaud et al. 2015). Eucharitids are well known for their bizarre morphological attributes, most notably the presence of extreme mesoscutellar processes that extend over the metasoma, which have been independently derived in various lineages in the tribe Eucharitini (Heraty et al. 2015). Heraty et al. (2015) referred to some of the work by Peréz-Lachaud to propose that the spines may have evolved to protect the wings as the ants remove the wasps from the colony to the exterior debris pile. Some of the most exaggerated mesoscutellar processes occur within a monophyletic lineage of Eucharitini that attack ants in the unrelated subfamilies Ectatomminae, Myrmeciinae, and Ponerinae.

Features of the pupa have not been used for discussions of phylogenetics in Chalcidoidea. Chalcidoid pupae are exarate, and can usually be grouped into those that are dorsoventrally flattened, as found in many Aphelinidae or Eulophidae or subcylindrical and more typically hymenopteriform as for most other Chalcidoidea (cf. Clausen 1940). Other than modifications to match the final adult form, it is rare to find excessive ornamentation of the pupa, with the exception in members of the planidial clade, for which we know of pupae in the Perilampidae (Chrysolampinae and Perilampinae) and Eucharitidae. Chrysolampinae likely have a basic pupal form similar to many pteromalids, although they have not been formally described. Askew (1980) and Darling and Miller (1991) both mention observing pupae of Chrysolampus Spinola but do not provide a description, which suggests that there was nothing remarkable about them. Within Perilampinae, the pupa generally lack any ornamentation on the head or mesosoma with at most some small tubercles on the metasoma (Clancy 1946, fig. 23; Darling 1999, fig. 7; Smith 1912, fig. 28); however, Monacon Waterson has extreme head ornamentation including two prominent curved horns on the top of the head and some small tubercles dorsally on the mesosoma (Darling and Roberts 1999, fig. 1).

In Eucharitidae, there can be excessive ornamentation and exaggeration of various structures on the pupa. In some cases the ornamentation is associated with exaggerated features of the adults but, in other cases, they are peculiar only to the pupa. Pupae have been documented in detail for Gollumiellinae: Gollumiella Hedqvist (Heraty et al. 2004); Oraseminae: Australosema Heraty \& Burks (as Orasema, Heraty 1994), Hayatose$m a$ Heraty \& Burks (as Orasema, Das 1963), Ibitya Heraty \& Burks (Burks et al. 2017), Ivieosema Heraty \& Burks (as Orasema, Reichensperger 1913), Orasema Cameron (11 spp.; Baker and Heraty in press; Burks et al. 2018; Carey et al. 2012; Chien and Heraty 2018; Heraty 1994; Heraty et al. 1993; Herreid and Heraty 2017; van Pelt 1950; Wheel- 
er and Wheeler 1937; Wheeler 1907), Timioderus Waterston (Heraty, 2000), and Zuparka Heraty \& Burks (as Orasema, Heraty 2000); and Eucharitinae: Athairocharis Heraty (Heraty, 2002), Austeucharis Bouček (Brues, 1919), Chalcura Kirby (Clausen, 1940), Dilocantha Shipp (Torréns, 2013), Eucharis (Clausen, 1940, morphology characteristics (or lack thereof) inferred by his reference to attributes of the other genera), Galearia Brullé ('Torréns, 2013), Lophyrocera Cameron (Torréns et al. 2008), Kapala Cameron (2 spp.; Clausen 1940; Pérez-Lachaud et al. 2006; Rocha et al. 2020), Mateucharis Heraty (Heraty, 2002), Neolosbanus Heraty (2 spp., Heraty 1994), Pseudochalcura Ashmead (Wheeler 1907), Pseudometagea Ashmead (Heraty and Murray 2013), Schizaspidia Westwood (3 spp; Clausen 1940; Heraty et al. 2015), and Stilbula Spinola (Clausen 1923; 1940). Characteristics of these pupae are often highly conserved across major lineages and offer strong support for monophyly or relationships of various groups.

Here we describe a new species from this group that was collected within cocoons of Bothroponera Mayr (Ponerinae) in South Africa. The developed adult, exuviae, and immature stages, including the pupa, allowed for an almost complete description of the life history of the parasitoid. We also describe other pupae from genera of Eucharitinae and examine their morphological traits within a phylogenetic context across the family.

\section{Materials and methods}

Terms for adults follow Heraty (2002) and Heraty et al. (2018). Terms for planidia follow Heraty and Darling (1984) and Heraty (2002). Terms for pupae follow Heraty et al. (2015). Specimens, including ant vouchers, are deposited in the Iziko South African Museum, Cape Town (SAMC). Photographs were taken using a Leica Imaging System with a Z16 APO A microscope and a 1.4 megapixel CCD camera (model LW1165C; Lumenera Corp., Ottawa, ON, Canada), and stacked using Zerene Stacker (version 1.04, Zerene Systems, LLC).

\section{Taxonomy}

\section{Eucharissa insolita sp. nov.}

http://zoobank.org/BB19D62E-9C39-4B97-BAA6-6BBC27EBB17A

Figures 1-10

Diagnosis. This species shares the following features with Eucharissa natalica Westwood: 16 antennal segments, flagellomeres of male with long dorsal rami, absence of a pronounced interantennal process, labrum transverse and hidden behind clypeus, hind tibia with one spur, and head and mesosoma dark blue. The major difference is the presence of basket-like, double-branched rami on all but the last flagellomere. This form of the antenna is most similar to E. stigmatica Westwood (cf. Westwood 1874, 

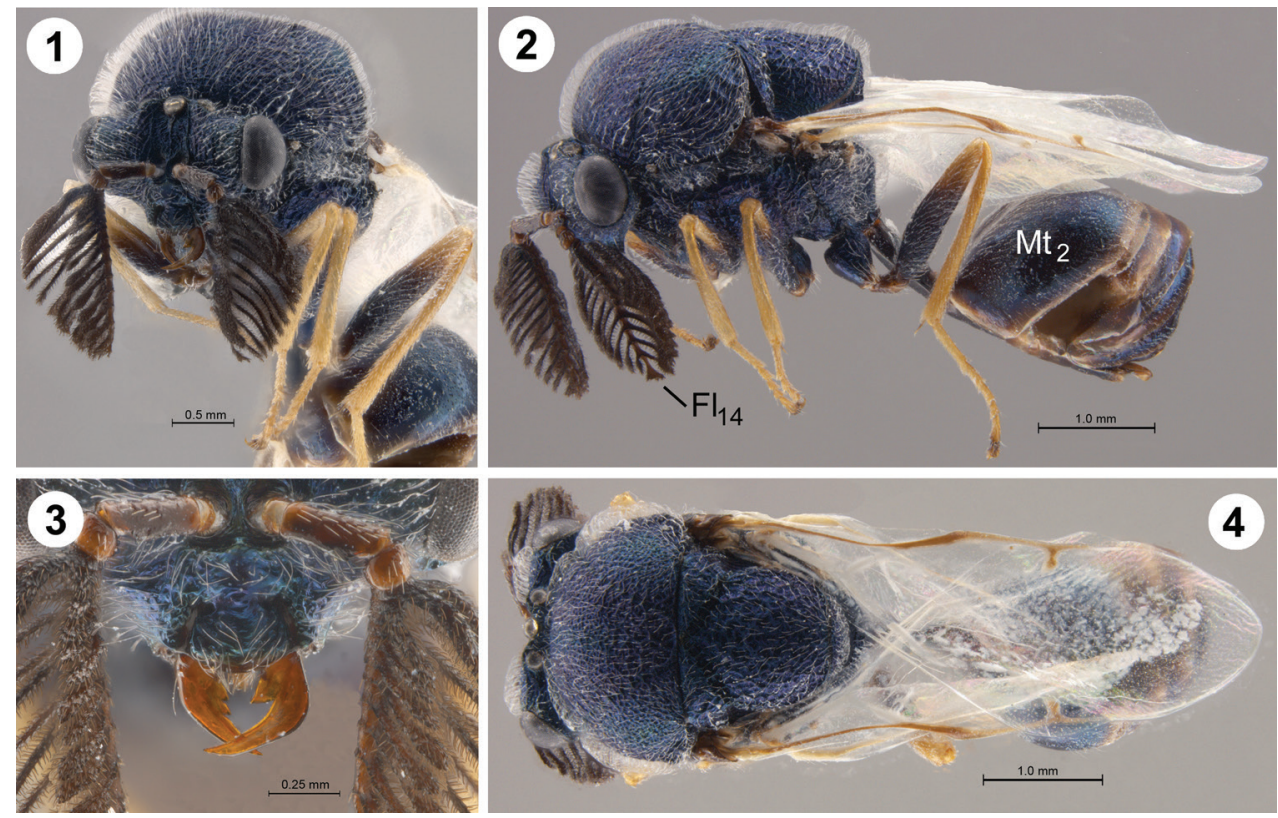

Figures I-4. Eucharissa insolita sp. nov., male I head and mesosoma, anterior $\mathbf{2}$ habitus, lateral $\mathbf{3}$ lower face, frontal 4 habitus, dorsal.

fig. XXVII 2a), but this other species has 19 flagellomeres. Compared to E. natalica, E. insolita has the mesoscutellar disc slightly longer than broad with the dorsal aspect flat in profile and on the same plane as the axillae, whereas in E. natalica the mesoscutellum is as long as broad, broadly rounded dorsally and elevated above the dorsal plane of the axillae (Heraty 2002, fig. 141). As well, the eyes of E. insolita are smaller and separated by $2.5 \times$ their height (versus $2.1 \times$ ) and the basal gastral tergite has an even covering of micropunctuation. Other species of Eucharissa have 18 or more antennal segments.

Male. Length, $5.6 \mathrm{~mm}$. Antenna dark brown; head, mesosoma, coxae, petiole, and most of gaster dark metallic blue; basal two-thirds of femora dark brown to black; apical gastral terga mostly brown; apex of femora, tibiae, and tarsi yellow; wings hyaline, venation brown.

Head $1.7 \times$ as broad as high. Frons rugose and covered by long fine setae, vertex bare just lateral to ocelli; vertexal carina sharp and extending laterally to eye margin. Eyes separated by $2.5 \times$ their height. Posterior genal margin carinate; malar space $0.8 \times$ height of eye and concave. Scrobes broadly impressed, laterally with weak vertical carinae in line with outer torular margin, and single median vertical carina extending to torulus. Toruli separated by a narrow ridge but not noticeably pronounced. Tentorial pits strongly impressed, supraclypeal area not demarked, clypeal region nearly smooth with sparse long setae. Labrum transverse and hidden behind clypeus, ventral margin with 5 tuberculate digits, each with a long seta that extends 
beyond clypeal margin. Mouthparts reduced, palpi absent. Antenna with 16 segments; scape almost reaching median ocellus; pedicel rounded and smooth; length of flagellum 1.3 $\times$ height of head, F2 $0.4 \times$ as long as broad basally, F2 as long as F3, following segments progressively longer along axis, F2-F10 with long paired flattened rami, decreasing in length apically, no distinct clava, F14 spatulate; flagellum pilose; multiporous plate sensilla not apparent.

Mesoscutum rugulose, about as long as broad and covered with long fine decumbent setae; notauli vaguely impressed and reaching transscutal articulation. Mesoscutellum and axilla rugose-areolate; mesoscutellar disc medially impressed and slightly longer than broad, dorsally flat in profile and on same plane as axilla, axillula lacking; frenum separated from mesoscutellum by non-carinate sulcus; entire surface of mesoscutellum with long fine decumbent setae. Propodeum broadly rounded, rugose-areolate, densely setose; propodeal spiracle circular with long narrow ventral excision of propodeum about as long as spiracle diameter. Mesopleuron rugoseareolate, lower mesepimeron mostly bare. Prepectus coarsely rugose-alveolate, upper half slightly swollen, distinguished from pronotum by shallow furrow. Hind coxa mostly smooth and shining, all coxae and femora with long fine setae; protibial spur thin and acuminate; one metatibial spur. Wings subtriangular; fore wing $2.9 \times$ as long as broad; venation complete (not interrupted); postmarginal vein $0.4 \times$ as long as marginal vein; stigmal vein about twice as long as broad and slightly recurved distally; entire wing with sparse short setae, marginal fringe absent. Hind wing with microsetae and sparse marginal fringe.

Petiole $3.0 \times$ as long as broad and $1.7 \times$ as long as the hind coxa, smooth with mediolateral patch of long setae, ventrally with thin medial sulcus. Gastral tergites smooth with sparse long recumbent setae and scattered micropunctuations; no tergal scar on $\mathrm{Gt}_{1}$. First gastral sternite $\left(\mathrm{Gs}_{1}\right)$ smooth without any constriction. $\mathrm{Gs}$, broadly rounded apically and setose. Aedeagus stout, digitus discoidal with short marginal spines, paramere broad with two apical setae. Cerci absent.

Female. Unknown.

Immatures. First instar (from exuvium, without head capsule, Fig. 9). Terga TI and TII fused dorsally, with 4 pairs of setae, ventrolateral pair as stout short spines; tergopleural line (tpl) present on TII to TVIII; relative to tpl, TIII with three pairs of setae, one dorsal pair, one posterior pair just lateral to tpl, and one pair on ventral margin, posteroventral corner acuminate; TIV with one dorsal pair of setae just medial to tpl, posteroventral margin rounded; TV with one dorsal pair of setae and one stout ventral pair; TVI as in TIV, but spine more robust, length exceeding width of tergum; TVII with posterior margin lateral to tpl with two acuminate posterior processes and one pair of ventral setae; TVIII similar to TVII but without setae and posterior margin medial to tpl crenulate; TIX with posteroventral margin long, spine-like and reaching to apex of TXII; TX tubular with crenulate posterior margin; TXI with broad posteromedial extension covering part of TXII; TXII with acute emarginate apex; cerci short and not reaching TXII apex. 


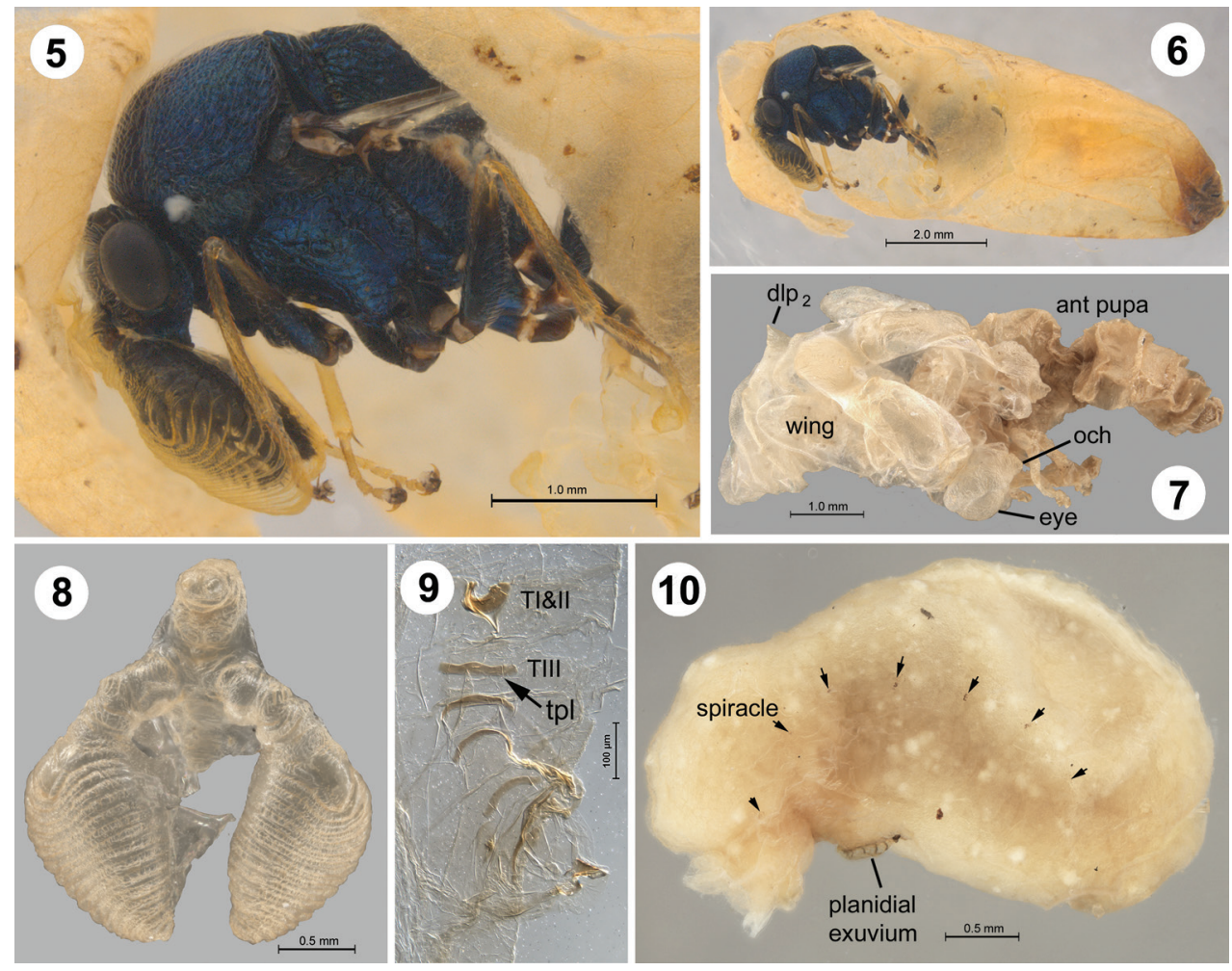

Figures 5-10. Eucharissa insolita sp. nov. 5-8 male: 5 head and mesosoma in place in cocoon $\mathbf{6}$ adult in place in cocoon $\mathbf{7}$ exuvium of body and host ant remains $\mathbf{8}$ exuvium cap from face and antenna, anterior 9 planidial exuvium taken from last-instar larva $\mathbf{I} 0$ last instar larva, lateral. Abbreviations: $\mathrm{dl}_{2}$, dorsolateral process; $\mathrm{T}$, tergum.

Second instar (Fig. 10). Length $3.9 \mathrm{~mm}$. Hymenopteriform in shape. Spiracles present on body segments $1-7$; body segments very finely tuberculate. Planidial exuvium attached to ventral thoracic region.

Pupa (from detached exuvium, antennal exuvium still attached to adult, Figs 5-8). Able to discern distinct ocellar horns (Fig. 7, och), a ventrolateral process $\left(\mathrm{vlp}_{2}\right)$, and a bladder-like dorsolateral process on gaster $\left(\mathrm{dl}_{2}\right)$; see Heraty et al. (2015) for a full description of each structure. A dorsal mesoscutellar swelling could not be observed, but may be present. A darkly pigmented tergal bar on the basal terga (as found in Schizaspidia) was not observed on the exuvium; notably the corresponding tergal scar was also not found on the adult, so this structure is considered to be absent in this species.

Holotype. South Africa: Mpumalanga: $2 \mathrm{~km}$ E R532 on God's Window sideroad, 1495m, 245ㄴ'32"S, 3051'38"E, 07 Dec 2016, N. Mbanyana \& S. van Noort; nest \#48 found at the base of a grass tussock with soil and gravel around the entrance; ex Bothroponera granosa (1 ठ, SAM-HYM-P095050); deposited in SAMC; ant host voucher (SAM-HYM-C028101; SAMC). Exuvium and host remains mounted 
on same point. Exuvium of planidium from same pupa mounted on slide (SAMHYM-P095051; SAMC).

Material examined. One second-instar larva (SAM-HYM-P095052, SAMC): same locality as holotype, 08 Dec 2016, N. Mbanyana \& S. van Noort; nest \#59; raised hillock nest about $20 \mathrm{~cm}$ high, fish tank gravel [= quartz gravel composed of evenly sized small stones] excavated and brought to surface; brood collected at about $5 \mathrm{~cm}$ below the ground level, workers down to $30 \mathrm{~cm}$ below; ex Bothroponera granosa (ant voucher SAM-HYM-C028104). Exuvium of planidium from same larva mounted on slide (SAM-HYM-P095053; SAMC).

Etymology. From the Latin insolitus for unusual or strange; gender feminine.

\section{New pupal illustrations of Eucharitini (detailed descriptions considered unwarranted)}

Stilbula sp. (Fig. 11).

Material examined. South Africa: Natal: Mzuke Game Res., Mantuma Rest Camp,

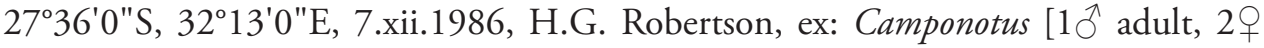
pupae, 4 larvae, SANC: SANC-HYMC00000245a-g].

Chalcura near polita (Fig. 12).

Material examined. Australia: NSW: Royal N.P., 7.xii.1975, P.S. Ward, ex: Rhytidoponera chalybaea, 1551 [1 $\hat{\jmath}$ teneral adult, 49 teneral adults, 19 pupa, UCRC: UCRCENT00478869-73].

Schizaspidia nasua (Figs 13, 14) (described in Heraty et al. 2015).

Material examined. West Malaysia: Negri Sembilan: Pasoh Forest Reserve, $2^{\circ} 58^{\prime} 56 " \mathrm{~N}, 102^{\circ} 18^{\prime} 20 " \mathrm{E}, 24 . \mathrm{i} .1991$, Roscizewski, rotten wood, ex: Odontomachus

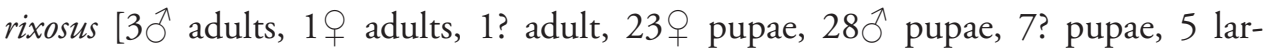
vae, 2 planidia, UCRC: UCRCENT00435815-74, UCRCENT00435886, UCRCENT00435890].

Kapala sp. (Figs 15, 16).

Material examined. Ecuador: Galapagos: Isabela Island, Cerro Azul, $4 \mathrm{~km}$ E Caleta Iguana, $300 \mathrm{~m}, 0^{\circ} 56^{\prime} 7^{\prime \prime} \mathrm{S}, 91^{\circ} 27^{\prime} 30^{\prime \prime} \mathrm{W}, 24 . v .1991$, J. Heraty, pampa transition, ex. Odontomachus bauri, H91-060 [1 9 pupa, UCRC: UCRCENT00478868]. 


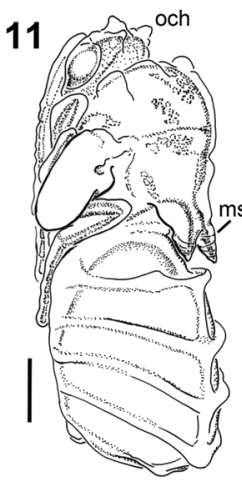

Stilbula

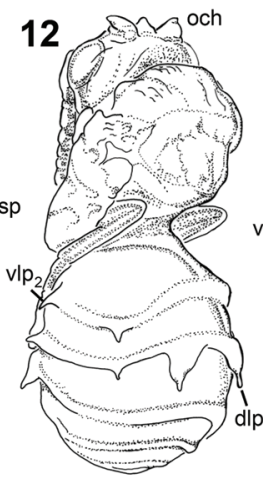

Chalcura

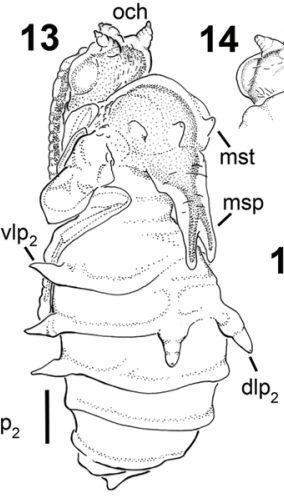

Schizaspidia

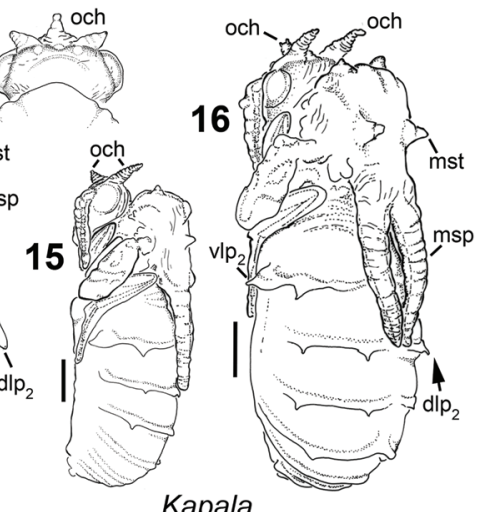

Kapala

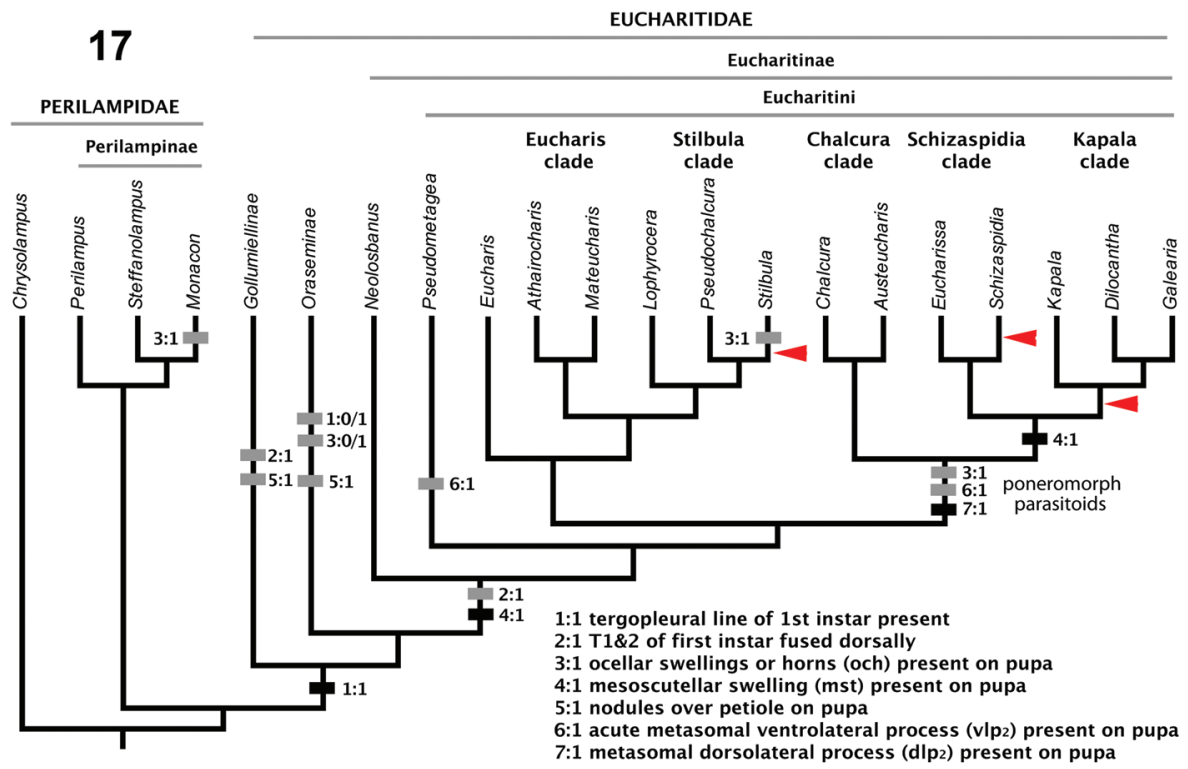

Figures II-17. II-16 pupae of Eucharitini described herein: II Stilbula I2 Chalcura I3-I4 Schizaspidia (14 head in dorsal view) I5-16 Kapala: 15 lateral view $\mathbf{1 6}$ dorsolateral view $\mathbf{1 7}$ characters of immatures mapped onto pruned phylogeny from Murray et al. (2013) using DELTRAN optimization (favoring parallelisms). Red triangles refer to independent derivations of the mesoscutellar processes (msp).

\section{Discussion}

The relationships of the genera of Eucharitidae with known pupae, pruned from Murray et al. (2013) are represented in Figure 17, with important characteristics of the immature stages mapped onto the phylogeny. Eucharissa is a member of the Schizaspidia clade within a more extensive monophyletic group that attack the ant subfamilies Ectatommatinae, Myrmeciinae, and Ponerinae (Heraty 2002; Fig. 17; Murray et al. 2013). We here report the first host record for the genus on Bothroponera (Ponerinae). 
Within the Schizaspidia clade, host records are known for Pogonocharis Heraty attacking Gamptogenys Roger (Ponerinae) and Schizaspidia Westwood attacking Diacamma Mayr and Odontomachus Latreille (Ponerinae) (Heraty 2002; Heraty et al. 2015). Given that Eucharissa + Ancylotropus (host unknown) are the sister group of the remaining members of the Schizaspidia-clade (Murray et al. 2013), and that Ponerinae are hosts for genera in the Chalcura and Kapala clades, we can make an assumption that Ponerinae are likely the ancestral host of the Schizaspidia clade.

Characteristic features of the planidium when compared to other members of the Chalcura, Schizaspidia and Kapala clades (cf. Heraty 2002; Murray et al. 2013) include the elongate processes on TIX and the emarginate apex of TXII (shared with Schizaspidia; Heraty et al. 2015). The minute cerci, which are shorter than TXII appear to be unique within this clade. The elongate bifurcating extensions of TIX are characteristic of other members of this clade, including Schizaspidia (Clausen 1940; Heraty et al. 2015; Ishii 1932) and Kapala Cameron (Pérez-Lachaud et al. 2006). The tergopleural line (tpl; 1:1 on Fig. 17) and the fused dorsal tergites (TI\&II; 2:1) are either features of Eucharitidae or Eucharitinae depending on whether the optimization favors parallelisms or reversals (Fig. 17), with both features unknown in any outgroups (Baker and Heraty 2020).

Pupae of Gollumiellinae and Oraseminae are nearly identical and both lack any ornamentation on the head, but all have 3-4 spherical nodules (3:1, character:state, Fig. 17) over the petiole, which are not associated with any structures on the adult. Evenlyrounded sublateral swellings that coincide with the posterolateral margin of the tergites (cf. Chien and Heraty 2018, fig. 23) are found in many of the species of Oraseminae, although we considered these as different from similar swellings found in Eucharitinae (Figs 12-16, vlp $_{2}$ ). Ibitya communis (Risbec) is the only exception to this general form, as it has generally exaggerated coarse swellings covering the body and often associated with tergal margins (Burks et al. 2017, fig. 37); it also has three prominent tubercles on the head associated with the ocelli which we scored the same as the ocellar horns $(3: 1)$ found in some Eucharitini, although they are likely independently derived.

Within Eucharitinae, there are two tribes. Neolosbanus (Psilocharitini) lack any ornamentation of the head or mesosoma and at most have small, sublateral, rounded swellings along metasomal segments 2 and 3 that are similar to those in Oraseminae. Within the Eucharitini, Pseudometagea and members of the Eucharis 'clade' (not monophyletic) also lack any ornamentation other than prominent sublateral swellings that come to an acute tip $\left(\mathrm{vlp}_{2}\right)$ on metasomal tergites $2-4$ in some of the species but not all. Within the Stilbula clade, Lophyrocera and Pseudochalcura lack ornamentation; however, Stilbula, as illustrated by Clausen (1923, fig. 9) has protuberances on the ocelli (och; 3:1), anterior dorsolateral mesosoma, and no ventrolateral swellings on the mesosoma, although each of the tergal margins are elevated (as shown in Fig. 11). The posterior extensions of the mesoscutellum (msp) are associated with the mesoscutellar processes of the adults, which are proposed to have developed independently in various Eucharitini (Fig. 17, red triangles).

What is remarkable are the seemingly specialized structures that are associated with the poneromorph ant parasitoids as represented by the Chalcura, Schizaspidia, and 
Kapala clades (Fig. 17). The ocellar horns (och; 3:1), also found in Stilbula, are present in all members of the Chalcura and Schizaspidia clades (Figs 12-16) and can become extremely exaggerated within the Kapala clade (Figs 15-17, and see examples in Torréns 2013). The ventrolateral metasomal processes $\left(\mathrm{vlp}_{2}, 6: 1\right)$ are present at least on the second metasomal tergite but in a similar form in Pseudometagea. All of the poneromorph parasitoids have bladder-like dorsolateral processes $\left(\mathrm{dl}_{2}\right)$ that can be exaggerated in size $(7: 1$; Figs 12,13$)$. Although difficult to interpret in some of the published figures, it would appear that the dorsal mesoscutellar swelling (mst, 4:1) is only known to occur in the Schizaspidia and Kapala clades. One additional feature, cuticular bars on the first metasomal tergite (discussed in Heraty et al. 2015) found in some species, but not Eucharissa, are associated with a tergal scar in the adult (cf. Heraty et al. 2015); however within these clades, they appear to be too variable even in the adults of the included species to score as any kind of synapomorphy of the group.

Within Eucharitidae, immatures can be extremely conserved and can offer valuable insights into the relationships at all levels of the phylogeny (Fig. 17). The tergopleural line (1:1) is a longitudinal line of weak cuticle likely associated with flexion of the tergites and increased mobility of the planidium. Within Oraseminae it occurs only in Orasemorpha (Heraty 2000) and one species of Orasema (Orasema tolteca Mann; Baker and Heraty in press), thus is mostly likely a synapomorphy of Eucharitidae (immatures unknown in Akapalinae). The fusion of dorsal tergites (2:1) in the planidium of Gollumiellinae and Eucharitinae is more likely to have evolved twice, as it is difficult to consider a simple reversal in all Oraseminae. Across Eucharitidae, the dorsal nodules over the petiole $(5: 1)$ in the pupae of Gollumiellinae and Oraseminae are unique features, although it is unclear if they are independently derived or gained and then lost in Eucharitinae; their function is unclear. Conical swellings dorsally on the mesoscutellum (mst, 4:1) are found only in the Schizaspidia and Kapala clades. The acute sublateral swellings on the metasoma $\left(\mathrm{vlp}_{2}, 6: 1\right)$ are found in all of the poneromorph parasitoid clade but also Pseudometagea, and it is unclear if they are also the same structures as found in Oraseminae and Neolosbanus. The dorsolateral bladder-like structures $\left(\mathrm{dlp}_{2}, 7: 1\right)$ appear to be found only in the poneromorph-attacking clade. The ocellar horns (och, 3:1) are one of the most unusual structures that occur in two clades within Eucharitidae, but become excessively exaggerated in the Kapala clade. What appear to be ocellar horns are also found in Monacon (Perilampidae) (Darling and Roberts 1999; hornlike) and Anastatus (Eupelmidae) (Clausen 1927, figs 8, 9; filamentous), but these are likely very different structures. In Gollumiellinae and Oraseminae, the pupae are naked in the broodpile, and potentially the swellings over the petiole might be associated with acquisition or concentration of cuticular hydrocarbons. It is difficult to propose a function for the various processes in Eucharitini, with the pupae being separated from the ant population inside the host cocoon. Whether the additional structures found on the pupae of these parasitoids of Ectatomminae, Myrmeciinae and Ponerinae is associated with the production of mimicking semiochemicals as discussed by (Pérez-Lachaud et al. 2015) remains to be seen.

Eucharissa is perhaps one of the most unique of the genera in Eucharitidae and even Chalcidoidea, but beyond their phylogenetic placement with molecular data, their high- 
ly specialized immature stages and host association provide strong morphological and biological evidence for their evolutionary position within this family of ant parasitoids.

\section{Acknowledgements}

Austin Baker contributed valuable comments on an early draft. We would like to thank Mpumalanga Parks Board provided collecting permits 5158 and 5536. This study was supported by an NRF grant GUN 98115 to SvN, and NSF grants DEB-1257733 and 1555808, and UCR Hatch grants to JMH.

\section{References}

Askew RR (1980) The biology and larval morphology of Chrysolampus thenae (Walker) (Hym., Pteromalidae). Entomologist's Monthly Magazine 115: 155-159.

Baker AJ, Heraty JM (2020) Larval morphology and life history of Eutrichosoma mirabile Ashmead and description of a new species of Eutrichosoma (Hymenoptera, Chalcidoidea). Journal of Hymenoptera Research 75: 67-85. https://doi.org/10.3897/jhr.75.47880

Baker AJ, Heraty JM (in press) A revision of the New World ant parasitoid genus Orasema (Hymenoptera: Eucharitidae) Zootaxa.

Brues CT (1919) A new chalcid-fly parasitic on the Australian bull-dog ant. Annals of the Entomological Society of America 12: 13-23. https://doi.org/10.1093/aesa/12.1.13

Burks RA, Heraty JM, Dominguez C, Mottern JL (2018) Complex diversity in a mainly tropical group of ant parasitoids: Revision of the Orasema stramineipes species group (Hymenoptera: Chalcidoidea: Eucharitidae).Zootaxa 4401: 1-107. https://doi.org/10.11646/zootaxa.4401.1.1

Burks RA, Heraty JM, Mottern J, Dominguez K, Heacox S (2017) Biting the bullet: revisionary notes on the Oraseminae of the Old World (Hymenoptera, Chalcidoidea, Eucharitidae). Journal of Hymenoptera Research 55: 139-188. https://doi.org/10.3897/jhr.55.11482

Carey B, Visscher K, Heraty J (2012) Nectary use for gaining access to an ant host by the parasitoid Orasema simulatrix (Hymenoptera, Eucharitidae). Journal of Hymenoptera Research 27: 47-65. https://doi.org/10.3897/jhr.27.3067

Chien I, Heraty JM (2018) Come and gone: Description of a new species of Eucharitidae (Hymenoptera) attacking Solenopsis (Hymenoptera: Formicidae) in Texas. Insect Systematics and Diversity 2: 1-7. https://doi.org/10.1093/isd/ixx012

Clancy DW (1946) The insect parasites of the Chrysopidae (Neuroptera). University of California Publications in Entomology 7: 403-496.

Clausen CP (1923) The biology of Schizaspidia tenuicornis Ashm., a eucharid parasite of Camponotus. Annals of the Entomological Society of America 16: 195-217. https://doi. org/10.1093/aesa/16.3.195

Clausen CP (1927) The bionomics of Anastatus albitarsis Ashm., parasitic in the eggs of Dictyoploca japonica Moore (Hymen.). Annals of the Entomological Society of America 20: 461-473. https://doi.org/10.1093/aesa/20.4.461 
Clausen CP (1940) The immature stages of Eucharidae (Hymenoptera). Journal of the Washington Academy of Sciences 30: 504-516.

Darling DC (1999) Life history and immature stages of Steffanolampus salicetum (Hymenoptera: Chalcidoidea: Perilampidae). Proceedings of the Entomological Society of Ontario 130: 3-14.

Darling DC, Miller TD (1991) Life history and larval morphology of Chrysolampus (Hymenoptera: Chalcidoidea: Chrysolampinae) in western North America. Canadian Journal of Zoology 69: 2168-2177. https://doi.org/10.1139/z91-303

Darling DC, Roberts H (1999) Life history and larval morphology of Monacon (Hymenoptera: Perilampidae), parasitoids of ambrosia beetles (Coleoptera: Platypodidae). Canadian Journal of Zoology 77: 1768-1782. https://doi.org/10.1139/z99-155

Das GM (1963) Preliminary studies on the biology of Orasema assectator Kerrich (Hymenoptera: Eucharitidae) parasitic on Pheidole and causing damage to leaves of tea in Assam. Bulletin of Entomological Research 54: 393-398. https://doi.org/10.1017/S0007485300048884

Heraty JM (1994) Classification and evolution of the Oraseminae in the Old World, with revisions of two closely related genera of Eucharitinae (Hymenoptera: Eucharitidae). Life Sciences Contributions, Royal Ontario Museum 157: 1-174. https://doi.org/10.5962/bhl.title.53489

Heraty JM (2000) Phylogenetic relationships of Oraseminae (Hymenoptera: Eucharitidae). Annals of the Entomological Society of America 93: 374-390. https://doi.org/10.1603/00138746(2000)093[0374:PROOHE]2.0.CO;2

Heraty JM (2002) A revision of the genera of Eucharitidae (Hymenoptera: Chalcidoidea) of the World. Memoirs of the American Entomological Institute 68: 1-359.

Heraty JM, Burks RA, Mbanyana N, van Noort S (2018) Morphology and life history of Psilocharis afra (Hymenoptera: Eucharitidae). Zootaxa 4482: 491-510. https://doi. org/10.11646/zootaxa.4482.3.3

Heraty JM, Darling DC (1984) Comparative morphology of the planidial larvae of Eucharitidae and Perilampidae (Hymenoptera: Chalcidoidea). Systematic Entomology 9: 309-328. https://doi.org/10.1111/j.1365-3113.1984.tb00056.x

Heraty JM, Hawks D, Kostecki JS, Carmichael AE (2004) Phylogeny and behaviour of the Gollumiellinae, a new subfamily of the ant-parasitic Eucharitidae (Hymenoptera: Chalcidoidea). Systematic Entomology 29: 544-559. https://doi.org/10.1111/j.0307-6970.2004.00267.x

Heraty JM, Mottern J, Peeters C (2015) A new species of Schizaspidia, with discussion of the phylogenetic utility of immature stages for assessing relationships among eucharitid parasitoids of ants. Annals of the Entomological Society of America 108: 865-874. https://doi. org/10.1093/aesa/sav062

Heraty JM, Murray E (2013) The life history of Pseudometagea schwarzii, with a discussion of the evolution of endoparasitism and koinobiosis in Eucharitidae and Perilampidae (Chalcidoidea). Journal of Hymenoptera Research 35: 1-15. https://doi.org/10.3897/jhr.35.6025

Heraty JM, Wojcik DP, Jouvenaz DP (1993) Species of Orasema parasitic on the Solenopsis saevissima complex in South America (Hymenoptera: Eucharitidae, Formicidae). Journal of Hymenoptera Research 2: 169-182.

Herreid JS, Heraty JM (2017) Hitchhikers at the dinner table: a revisionary study of a group of ant parasitoids (Hymenoptera: Eucharitidae) specializing in the use of extrafloral nectaries for host access. Systematic Entomology 42: 204-229. https://doi.org/10.1111/syen.12206 
Ishii T (1932) Some Philippine eucharids with notes on their oviposition habits. Bulletin of the Imperial agricultural Experiment Station, Nishigahara 3: 203-212.

Murray E, Carmichael AE, Heraty JM (2013) Ancient host shifts followed by host conservatism in a group of ant parasitoids. Proceedings of the Royal Society, B 280: 1-9. https:// doi.org/10.1098/rspb.2013.0495

Pérez-Lachaud G, Bartolo-Reyes JC, Quiroa-Montalván CM, Cruz-López L, Lenoir A, Lachaud J-P (2015) How to escape from the host nest: imperfect chemical mimicry in eucharitid parasitoids and exploitation of the ants hygenic behavior. Journal of Insect Physiology 75: 63-72. https://doi.org/10.1016/j.jinsphys.2015.03.003

Pérez-Lachaud G, Heraty JM, Carmichael AE, Lachaud JP (2006) Biology and behavior of Kapala (Hymenoptera: Eucharitidae) attacking Ectatomma and Gnamptogenys (Formicidae: Ectatomminae) in Chiapas, Mexico. Annals of the Entomological Society of America 99: 567-576. https://doi.org/10.1603/0013-8746(2006)99[567:BABOKH]2.0.CO;2

Reichensperger A (1913) Zur kentnis von Myrmecophilen aus Abessinen, I. Zoologische Jahrbücher. https://doi.org/10.5962/bhl.part.16717

Rocha FH, Lachaud JP, Pérez-Lachaud G (2020) Myrmecophilous organisms associated with colonies of the ponerine ant Neoponera villosa (Hymenoptera: Formicidae) nesting in Aechmea bracteata bromeliads: a biodiversity hotspot. Mymecological News 30: 73-92.

Smith HS (1912) IV. The chalcidoid genus Perilampus and its relations to the problem of parasite introduction. US Department of Agriculture, Technical Series 19: 33-69.

Torréns J (2013) A review of the biology of Eucharitidae (Hymenoptera: Chalcidoidea) from Argentina. Psyche 2013 926572: 1-14. https://doi.org/10.1155/2013/926572

Torréns J, Heraty JM, Fidalgo P (2008) Biology and description of a new species of Lophyrocera Cameron (Hymenoptera: Eucharitidae) from Argentina. Zootaxa 1871: 56-62. https:// doi.org/10.11646/zootaxa.1871.1.2

van Pelt AF (1950) Orasema in nests of Pheidole dentata Mayr (Hymenoptera: Formicidae). Entomological News 61: 161-163.

Vander Meer RK, Jouvenaz DP, Wojcik DP (1989) Chemical mimicry in a parasitoid (Hymenoptera Eucharitidae) of fire ants (Hymenoptera: Formicidae). Journal of Chemical Ecology 15: 2247-2261. https://doi.org/10.1007/BF01014113

Westwood JO (1874) Thesaurus Entomologicus Oxoniensis; or illustrations of new, rare, and interesting insects, for the most part contained in the collections presented. Oxford, 328 pp. [205, 240 pls.] https://doi.org/10.5962/bhl.title.14077

Wheeler GC, Wheeler J (1937) New hymenopterous parasitoids of ants (Chalcidoidea, Eucharidae). Annals of the Entomological Society of America 30: 171-172. https://doi. org/10.1093/aesa/30.1.163

Wheeler WM (1907) The polymorphism of ants with an account of some singular abnormalities due to parasitism. Bulletin of the American Museum of Natural History 23: 1-108. 